\title{
Romania: a non-interventionist family support policy?
}

\author{
Iulian Stănescu \\ PhD., Research Institute for Quality of Life, Romanian Academy \\ stanescu.iccv@gmail.com
}

DOI:10.5901/mjss.2014.v5n19p19

\begin{abstract}
The challenges of population decline in Europe have stimulated interest and debate about family support policies. Based on an overview of family support policies in several European countries, this paper aims to provide an assessment about which model best describes the current policy setup in Romania. Our starting point is the typology of family policies in Europe developed by Gauthier (1996), which includes four models of family policies: pro-natalist, pro-traditional, pro-egalitarian and non-interventionist. We then set out to compare the key features of the policies in place in several relevant European countries for each of these models. The methodology relies on secondary analysis of studies and national level policy documents and sources on family support policies. The comparative framework includes (1) the nature, objectives, and goals of the policies, (2) the content, i.e. benefits and services, (3) a review of the recent research findings on the impact of these policies. Regarding the content of family policies, we will focus on the main types of support: cash support for families (allowances, tax credits, and means-tested cash benefits), leave benefits for working parents (maternity and parental leave schemes), and childcare services for families (provision and subsidies). Since policy outcomes vary according to different social context, we also pay attention to social, political and demographical trends. In addition to the abovementioned points, the analysis of the Romanian family support policies takes into account the changes made in 2010-2011. Like many other European Union Member States, Romania opted for austerity as the policy response to the recession triggered by the crash of 2009. In terms of policy decisions, this translated in a reform of the social benefits system and of the labour laws, resulting in cuts to cash support schemes for families and reduced leave benefits for working parents. The paper argues that the overall outcome puts Romania in the noninterventionist model of family support policies.
\end{abstract}

Keywords: family support policies, Romania, Europe, population decline, fertility, cash transfers, leave benefits, childcare service

\section{Introduction}

With nearly all European countries experiencing a long-term decline in fertility, the interest for policies related to demographic changes is on the rise. Europe's demographic decline raises major economic, social, and political issues. Compared with a decade ago, these issues are visible at present and likely to be more so in the future. For the economy, an overall population decline and aging societies bring fundamental changes to the labour market, as well as a reduction of the potential for economic growth. With less people to pay taxes, the sustainability of public finances and social insurance systems, especially pensions and healthcare, is under question. Issues arising from immigration and emigration are reeling in politics and society at large. Against this backdrop, the European Union's (EU) 2020 agenda of smart, sustainable and inclusive growth faces a risk of going the way of its predecessor, the failed Lisbon Strategy.

This paper is intended to contribute to the emergence of a climate of informed debate in Romania on the relationship between social policy, especially family support policies, and demographic change. The main aim is to asses which model best describes the current policy setup in Romania. Based on an overview of the main models of family policies in Europe - pro-natalist, pro-traditional, pro-egalitarian and non-interventionist - the paper intends to provide a setting for the choices available to the Romanian policy makers in order to mitigate the effects of low fertility and population decline.

\section{Method}

The methodology relies on a secondary analysis of studies, policy documents and other sources regarding family support policies. We start from the main models of family policies in Europe out forward in the typology developed by Gauthier (1996). Alongside a brief overview of these models, covering their main features, attention is also paid to the social, demographical and political context. Another aim of the overview is to develop a comparative framework based on the key 
abovementioned elements with the following structure: (1) the nature, objectives, and goals of the policies, (2) the content: cash support, benefits for working parents, and child care services, (3) the outcome, via a brief review of recent research findings on the impact of these policies. In turn, each of the content elements features its own categories. Cash support for families includes allowances, tax credits and means-tested benefits. Leave benefits for working parents comprise maternity and parental leave schemes. Childcare services for families consist both of in-kind provision and cash subsidies.

The second part of the paper looks into the Romanian family support policies through the abovementioned comparative framework. Since Romania, like many other European Union member states opted for austerity policies as a response to the Great Recession triggered by the crash of 2009 , we consider sensible to look at the policy setting before and after the 2010-2011 cuts in social spending and overall austerian overhaul of policies.

\section{Population policies versus family policies}

The terms used to describe public policy aimed at influencing demographic change provide an interesting issue. The most common terms used are population policies and family policies. Of the two, the former is the first in terms of chronology. Its original scope included measures aimed to have an impact on the population structure, explicitly linked to indicators such as birth rate or fertility rate (Grant et al., 2004, p. 19). However, just referring to the indicators without the mechanism of change might seem vague, even devoid of content. While the policy goals refer to the population as a whole, the area of intervention is at the micro-level of family unit or the individual. For instance, a broader definition put forward by Livi-Bacci (1974, p. 192) describes population policy as "legislation, and measures of economic and social policy [that] influence the behaviour of the individual and contribute to modify the environment, considered in the broad sense of the word, in which decisions are formed and taken: among them the decision to marry, to have children, or to migrate either within or abroad."

In broad terms, family policy covers areas of government intervention regarding family well-being and measures aimed towards families with children (Aldous and Dumon, 1980). In practical terms, the distinction between population and family policies is blurred. Despite the stated general policy objective being different - population versus family - there is a source of overlap in that the crux of population policies regarding fertility entails changes in a family's perceptions and attitudes of the costs and benefits of having children (David, 1992). Perhaps the main difference comes from an ideological point of view. On the one hand, the matter of the government's intervention in decisions taken by individuals and families is debatable. This argument is compounded by the experience of the strict procreative policy of former Communist regimes in Central and Eastern Europe, particularly Romania and East Germany, encapsulated in the term pro-natalist policy. Therefore, it becomes more politically risky for a government to explicitly set as a primary policy objective a rise in births by encouraging families to have more children. It is in this context, that family policy, instead of population policy, could be perceived as a more neutral framing of a policy mix geared toward the same goal. Another viewpoint on the framing issue, is arguably in Kamerman and Kahn's (1978) observation that family policies could be explicit, implicit or not exist at all. An explicit policy is one that stems from a strategic policy document that states the goal and sums up all the measures intended to attain it. As a result, family or population policy tends to be implicit or lacking at all.

\section{Typology of family support policies}

A large difference in family policies across nations is to be expected. The existence of policy goals, level of state intervention and support vary from country to country. Based on a comparative analysis of 22 industrialised countries, Anne Gautheir (1996) put forward a typology of family support policies comprising four models: pro-natalist, pro-traditional, pro-traditional, pro-egalitarian, non-interventionist. This section will briefly explore the main trends of each of these models, before moving to assess which of them best describes the policy setup in Romania as of 2014.

The pro-natalist model features a situation of government concern with low fertility and a policy setup with an explicit goal in raising the birth or fertility rate with a broad range of measures. The main task is to encourage families to have children, which is to be achieved through decreasing the costs of raising children and changing, in the medium and long term, general attitudes towards the idea of having children. Decreasing the cost of child raising means high levels of cash support, both in terms of child allowance and tax credits for working parents. Strong legislation is in place for maternity and paternity leave. Child care facilities are provided and generous subsidies are in place for covering its cost in the family budget. France is the best example for this policy model. Having faced the issue of low birth rate from the 19th century, France engaged in the early 1990s on a renewed pronatalist policy. Close to the mid 2010s, the policy is a qualified success, with France enjoying one of the highest fertility rates in Europe and very close or around the replacement rate (2.1) (Thevenon, 
2009). In terms of financing, this was possible public spending on family policy of around $4 \%$ of GDP (Heran, 2013). A political consensus around this policy ensured its endurance regardless of the ideological orientation of the government of the day. The current policy course was initiated by the conservative Gaullist government of Eduard Balladur in the early 1990s, and continued by all subsequent governments.

The pro-traditional model derives from a policy goal of maintaining the family. In this case, there is an implicit goal not linked with increasing fertility of the birth rate, but with a rather paternalistic of preserving the traditional family. In broad terms, while the state emphasis family support, families and voluntary organisations (community organisations, the church) are regarded as the most important sources of material support. The level of cash support tends to be medium at best, as well as the benefits for working parents. Maternity and parental leave is short, just 1 year. The provision of child care services is low, due to the traditional view of the mother as responsible of raising the children. Germany is the best example for this model. Its impact on the birth rate was negative, with Germany having one of the lowest birth rates in Europe and a rapidly aging society. Being a major debate issue in Germany, the government has recently taken some measures linked to raising the birth rate and away from the traditional model (Spiegel, 2011).

The pro-egalitarian model main goal is to achieve gender equality through an environment designed to help women balance employment and family life, while at the same time increasing the role of the father in child care. As a result, this model features medium levels of cash support, and high levels of benefits for working parents and especially child care services. Ideologically, it is highly influenced by the feminist movement, in the sense of achieving gender neutrality and a better worklife balance for women. Northern European countries associated with the Scandinavian social model and gender equality, such as Sweden and Denmark, provide good examples of the model (Chiu et al., 2008). In terms of effect on the birth rate, while lower than the pro-natalist model to around 1.7-1.9, it places the Northern European well above the European average, thus mitigating the long-term effects of population decline.

The non-interventionist model, as its name suggests, has no goal at all regarding the birth rate. Usually explicitly, its goal is to provide some support for families at risk of poverty and social exclusion. Therefore the level of support in terms cash transfers, benefits for working parents, including maternity and paternity leave and child care services is at a very low level. The participation of working mothers in the labour market is encouraged by limiting benefits. Poor families are provided only with selective, means-tested benefits. Businesses enjoy financial incentives for providing child care services. This model is strongly linked with a neo-liberal ideology, with its emphasis on the role of the market, individual and family selfsufficiency and belief against state intervention in society and individual life. Britain during the 18-year period of Conservative governments led by Margaret Thatcher and John Major in the 1980s and 1990s is the leading example for this model (Chiu et al., 2008).

\section{Population trends in Romania}

During the 20th century, Romania experienced all the phases of the demographic transition, from high birth rates and high mortality to the current situation of low birthrate and low mortality, and negative population growth (Zamfir, 1999). After the fall of Communism in 1989, the transition to capitalism sent the economy went into a freefall and increased poverty, which led to severe social pathologies (Zamfir, 2004, p. 51). In turn, this led to a massive decline of births and marked increase of mortality (see tables 1 and 2). This development is not unique in Romania. All former Communist countries experienced the same phenomena, caused by the "shock therapy" strategy for the transition to capitalism (Stuckler et al., 2009). A quarter of century since the 1989 Revolution, Romania's population declined by 16\%, from 23.2 million down to 20 million, the main causes being emigration and the natural population decline. Regardless of the future emigration dynamic, current projections point to a total population of less than 15 million in 2050 (Gheţău, 2012p. 47-48). Obviously, this has massive economic and social consequences. The total fertility rate collapsed from around the replacement level in 1989-1990 to 1.3-1.4 for much of the past 20 years. Any discussion about a family or population policy in Romania needs to be set in this context.

\section{Policy goals: the nature and objectives}

Family policy in Romania has three main goals: (1) to enable a better work-life balance through increase access to child care services, (2) to provide support poor families through mainly through means tested benefits, and (3) to provide social care for abandoned children through the child protection system. All three are mentioned in the Government's investiture program. Policy documents outlining the government's strategy regarding poverty reduction, employment and child 
protection for 2014-2020 are either in place or in development. There is no implicit or explicit goal within family policy regarding the birth rate or fertility, despite the country's dire demographic trends. The term population policy is avoided altogether. Two main reasons could be considered. First, the backlash following almost 25 years of harsh pro-natalist policy enforced by the Communist regime. In the mid 2000s, Romanian social policy experts stressed this argument and the lack of financial resources during the transition (Mărginean, 2004, p. 212-218). A second reason has to do with low policy development capability, the Labour Ministry being heavily dependent on outside policy content supplied by international institutions such as the World Bank and UNICEF or overly reliant on the recommendations of the European Commission.

\section{Policy content: benefits and services}

The policy content follows the abovementioned goals. The family support system was built around cash support. By far the main benefit was child allowance. After the 1989 Revolution, its value severely declined in real terms, from $10.5 \%$ of the average wage in 1989 to 2.4\% in 2007 (Popescu, 2008, p. 247). In 2008, the child allowance for children up to 2 years old increased by more than eight times. In 2009, child allowance for children from 2 to 18 doubled. This kept the latter below $3 \%$ of the monthly gross wage, but increased the former to $10.5 \%$, virtually the same level as 25 years before. Besides child allowance, other means tested allowances, such as for the single parent family were introduced in the $2000 \mathrm{~s}$. In addition, the income tax system provides a tax credit for children. However, these measures amount to around 20 euros per month each (Stănescu et al., 2012).

The main benefits for working parents are maternity or parental leave and a labour code provision guaranteeing the parent's job for up to 6 months after returning from leave. The rules leave changed during the 2000s from a quota (85\%) of the average monthly wage for the previous year of the parent taking leave, usually the mother, to a quota $(85 \%)$ of the national average wage to a fixed sum set by the government around a quota (75\%) of the national average wage (Popescu, 2008, p. 250). The reason for these changes lie with the fact that women were paid less than the national wage and on and off budgetary constraints. In 2008, an significant change occurred. Once more, the benefit was set at $85 \%$ of the previous wage, but with a low and high mark. The duration of parental leave was 2 years, with another year available for children with disabilities. The lower mark was marginally higher than the minimum wage. In 2010, austerity policies imposed cuts on the parental leave benefit. For the first year, the benefit was cut to $75 \%$ of the previous wage, while also reducing the maximum level. For the second year it was further cut to a maximum of around $60 \%$ of the gross national average wage (Stănescu et al., 2012). In terms of public financing, the value of all cash and benefits for working parents amount to around $1 \%$ of GDP, with child allowance and parental leave benefit covering close to $90 \%$ (Popescu, 2008, p. 246).

Child care services went into decline in the 1990s, as nurseries and kindergartens no longer received financial support from state owned enterprises or public financing. A severe and quick reduction in births in that period further added pressure for the closing of many units. As a result, there was a crisis in kindergarten beds in the $2000 \mathrm{~s}$, with the mild recovery of births in the latter part of the decade. The provision of child care services, either in kind in nurseries or subsidized is a major problem in Romania. On the other hand, the authorities have put in place a system of sanctioned vouchers for child care services provided or supported by businesses.

\section{Policy outcome: impact during boom and austerity}

The birth rate and fertility indicators did show a mild recovery during the boom years of the late 2000s. On the one hand, this was made possible by a change of policy with the substantial increase of existing benefits, mainly child allowance and paternal leave, and the introduction of new universal benefits. This allowed the fertility rate to recover form 1.3 to 1.6 and the birth rate to remain steady around 10.4 per 1, 000 inhabitants, despite ever reducing fertile cohorts and emigration. In addition to social policy, the economic boom obviously acted as indirect policy reinforcing these trends. The austerity response to the economic crisis involved massive cuts to cash support, a reduction of the real and even nominal value of benefits and a turn towards means-testing. Coupled with a recession during 2009-2010, the result was a fall in the birth rate and the fertility rate back to the lowest levels during the past quarter century. From an ideological standpoint, it is closer to neoliberalism, with its emphasis on individual and family self-sufficiency and belief against state intervention in society and individual life, except for minimal support. 


\section{Discussion}

This aim of this paper was to identify which model best describes family policy in Romania. Using secondary analysis of studies and policy documents, a comparative framework was developed comprising three categories: (1) the nature, objectives, and goals of the policies, (2) the content: cash support, benefits for working parents, and child care services, (3) the outcome, via a brief review of recent research findings on the impact of these policies. Our particular area of concern was family policy with an explicit or implicit goal in raising the birth or fertility rate with a broad range of measures. Population policy is another term used for this kind of policy, although it is less widely used.

Out of the four models - pro-natalist, pro-traditional, pro-egalitarian and non-interventionist -we argue Romania is in the non-interventionist category. First, this comes from a non-existent family policy linked to an objective of raising the birth rate or the fertility rate. Indeed, family policy in Romania is mainly concerned with other objectives, such as work-life balance, support for poor families and social care for abandoned children. Secondly, although a system of cash support and benefits for working parents is in place, it not in a position to change in the perceptions and attitudes of the costs and benefits of having children due to the low level of the benefits. Moreover, the recent austerity policy drive delivered cuts in these benefits and more means testing. Last but not least, support for child care services is low. Availability and access to child care is very low for nurseries and still problematic for kindergarten. The overall approach of government could be summed up as non-interventionist. The enforced pro-natalist policy of the previous regime and low policy development capabilities compound a lack of response to the great challenges stemming from population decline and an aging society. In this context, this paper intended to contribute to the emergence of a climate of informed debate in Romania on the relationship between social policy, especially the link between family support policies and demographic change. A secondary objective was to provide a setting for the choices available to the Romanian policy makers from other models of family policies.

\section{Acknowledgement}

This paper is made and published under the aegis of the Research Institute for Quality of Life, Romanian Academy, as a part of a research programme co-funded by the European Union within the Operational Sectorial Programme for Human Resources Development through the project for Pluri and interdisciplinary in doctoral and post-doctoral programmes. Project Code: POSDRU/159/1.5/S/141086.

\section{References}

Aldous, J. \& Dumon, W. (1980) European and United States perspectives on family policy: a summing up. IN Aldous, J. \& Dumon, W. (Eds.) The politics and programs of family policy: United States and European perspectives. Leuven, Leuven University Press.

Chiu, S. W., Wong, R. K. \& Yip, T. (2008) A Cross-National Comparison of Family Policy Hong Kong, Hong Kong SAR Government.

David, H. P. (1992) Abortion in Europe, 1920-91: a public health perspective. Studies in Family Planning, 23, 1, 1-22.

Gauthier, A. H. (1996) The State and the Family: A Comparative Analysis of Family Policies in Industrialized Countries Oxford, Clarendon Press.

Gheţău, V. (2012) Drama noastră demografică. Populaţia României la recensământul din octombrie 2011, Bucureşti, Compania.

Grant, J., Horens, S., Sivadasan, S., Loo, M. v. h., DaVanzo, J., Hale, L., Gibson, S. \& Butz, W. (2004) Low Fertility and Population Ageing. Causes, Consequences and Policy Options, RAND Corporation.

Heran, F. (2013), Fertility and family-support policies: what can we learn from the European experience? Presented at Conference, Name Conference, Location.

Kamerman, S. B. \& Kahn, A. J. (1978) Family policy: government and families in fourteen countries, New York, Columbia University Press.

Livi-Bacci, M. (1974) Population Policy in Western Europe. Population Studies, 28, 2, 191-204.

Mărginean, I. (2004) Politica socială. Studii 1990-2004, Bucureşti, Expert. 
Popescu, R. (2008) Sistemul de suport destinat familiei si copilului. IN Mărginean, I. \& Precupeţu, I. (Eds.) Calitatea vieţii şi dezvoltarea durabilă. Politici de întărire a coeziunii sociale. Bucureşti, Expert.

Spiegel, (2011) A Land Without Children: Why Won't Germans Have More Babies? Der Spiegel, http://www.spiegel.de/international/germany/a-land-without-children-why-won-t-germans-have-more-babies-a-

\section{1.html.}

Stănescu, S., Dragotoiu, A. \& Marinoiu, A. (2012) Beneficiile de asistenţă socială gestionate de Ministerul Muncii, Familiei şi Protecţiei Sociale. Calitatea Vieţii, XXIII, 3, 239-266.

Stuckler, D., King, L. \& McKee, M. (2009) Mass privatisation and the post-communist mortality crisis: a cross-national analysis. Lancet, 373, 399-407.

Thevenon, O. (2009) Does Fertility Respond to Work and Family-life Reconciliation Policies in France? IN Takayama, N. \& Werding, M. (Eds.) Fertility and Public Policy: How To Reverse the Trend of Declining Birth Rates. London, MIT-Press.

Zamfir, C. (1999) Tranziţia demografică şi problemele sociale asociate. IN Zamfir, C. (Ed.) Politici sociale în România: 1990-1998. Bucureşti, Expert.

Zamfir, C. (2004) O analiză critică a tranziţiei. Ce va fi "după"?, Iaşi, Polirom.

\section{Tables}

Table 1. Total fertility rate in Romania 1989-2012

\begin{tabular}{llllllllllll}
\hline 1989 & 1990 & 1991 & 1992 & 1993 & 1994 & 1995 & 1996 & 1997 & 1998 & 1999 & 2000 \\
\hline 2,2 & 1,8 & 1,6 & 1,5 & 1,4 & 1,4 & 1,3 & 1,3 & 1,3 & 1,3 & 1,3 & 1,3 \\
\hline 2001 & 2002 & 2003 & 2004 & 2005 & 2006 & 2007 & 2008 & 2009 & 2010 & 2011 & 2012 \\
\hline 1,2 & 1,3 & 1,3 & 1,3 & 1,4 & 1,4 & 1,4 & 1,6 & 1,6 & 1,6 & 1,5 & 1,3 \\
\hline
\end{tabular}

Source: Romanian Statistical Yearbook 2013

Table 2. Birth rate, crude (per 1, 000 people) in Romania 1989-2012

\begin{tabular}{llllllllllll}
\hline 1989 & 1990 & 1991 & 1992 & 1993 & 1994 & 1995 & 1996 & 1997 & 1998 & 1999 & 2000 \\
\hline 16 & 13,6 & 11,9 & 11,4 & 11 & 10,9 & 10,4 & 10,2 & 10,5 & 10,5 & 10,4 & 10,5 \\
\hline 2001 & 2002 & 2003 & 2004 & 2005 & 2006 & 2007 & 2008 & 2009 & 2010 & 2011 & 2012 \\
\hline 9,8 & 9,7 & 9,8 & 10,1 & 10,4 & 10,4 & 10,3 & 10,8 & 10,9 & 10,5 & 9,7 & 9,0 \\
\hline
\end{tabular}

Source: Romanian Statistical Yearbook 2013 